\title{
Profile of Parenting Style in University Students with Tendency of Hedonism Lifestyle
}

\author{
Maura Tuzzahrah Ramadhani ${ }^{1}$, Erikavitri Yulianti ${ }^{2^{\star}}$, Lilik Djuari ${ }^{3}$
}

\author{
${ }^{1}$ Faculty of Medicine, Universitas Airlangga, Surabaya. \\ 2 Department of Psychiatry, Faculty of Medicine, Universitas Airlangga - Dr. Soetomo General Hospital, Surabaya. \\ ${ }^{3}$ Department of Public Health and Preventive Medicine, Faculty of Medicine, Universitas Airlangga - Dr. Soetomo General \\ Hospital, Surabaya.
}

\begin{abstract}
A B S T R A C T
Introduction: Hedonism has been a trending lifestyle, most notably in the youth community, one factor that contributes to hedonism lifestyle is parenting style. This research is to determine the profile of parenting style with the tendency of hedonism lifestyle in university students of Medicine Program Faculty of Medicine Universitas Airlangga Batch 2015.
\end{abstract}

Methods: This study is analytic observational research with cross-sectional design and uses a questionnaire as research instrument that is given to 200 respondents

Results: 16 university students raised with authoritarian parenting style (8.30\%), 169 students raised with authoritative parenting style $(87.56 \%)$, and 8 students raised with permissive parenting style (4.14\%). Students with the tendency of hedonist lifestyle in the low category are 45 students $(23.32 \%)$, in the intermediate category is 146 students $(75.64 \%)$, and in the high category is 2 students $(1.04 \%)$. The tendency of hedonism lifestyle is low in 2 students raised with authoritarian parenting style (1.04\%), 42 students raised with authoritative parenting style $(21.76 \%)$, and 1 student raised with permissive parenting style $(0.52 \%)$. The tendency of hedonist lifestyle in category intermediate has 12 students raised with authoritarian parenting style (6.22\%), 127 students raised with authoritative parenting style $(65.80 \%)$, and 7 students raised with permissive parenting style $(3.62 \%)$. In the high tendency category of hedonist lifestyle are 2 students raised with authoritarian parenting style $(1.04 \%)$. Using Kruskal-Willis test, it was found that $p=0.123$.

Conclusion: Most parenting style used in the students is authoritative. Category of the tendency of hedonist lifestyle in most students is in the intermediate category. The tendency of hedonist lifestyle in the low category has most students raised with an authoritative parenting style. The tendency of hedonism lifestyle in the intermediate category has most students raised with an authoritative parenting style. The tendency of hedonist lifestyle in the high category has most students raised with an authoritarian parenting style. And it was found that there is no significant difference in proportion in parenting style with the tendency of hedonism lifestyle with $p>a$.

*Correspondence: rikahus@yahoo.co.id

JUXTA: Jurnal IImiah Mahasiswa Kedokteran Universitas Airlangga

p-ISSN: 1907-3623; e-ISSN: 2684-9453

DOI: 10.20473/juxta.V10I12019.29-33

Open access under Creative Commons Attribution-ShareAlike 4.0 International License (CC-BY-SA)

\section{ARTICLE INFO}

Article history:

Received 26 December 2018

Received in revised form 22 January 2019

Accepted 24 January 2019

\author{
Keywords: \\ Parenting style, \\ Tendency of hedonism, \\ Universitas Airlangga students, \\ Surabaya, \\ Indonesia.
}




\section{Introduction}

Lately, university students have been facing a lot of complicated lifestyle issues. There are all kinds of deviant behavior that are unconsciously being followed by most of Indonesian University Students, one of them is extravagant money usage otherwise known as hedonism. Hedonist lifestyle has been in trend lately the circle of university students. One of the reasons why this lifestyle is being followed by students is because they want to attract other people's attention, in addition to approval by their inner circle, most notably their peers. Hedonism is a form of expression or behaviour of trying something new where pleasure matters more than doing positive things. ${ }^{1}$ According to Aristippus who spread the concept of hedonism to the world, hedonism means "A view that has been unconsciously applied by all humanity where they always seek pleasure and avoid pain". The followers of this view consider partying, having fun, and having a luxurious appearance as their main goals in life. The point is, they have a very materialistic view of the world.

Among university students, hedonism is associated with consumptive behavior. This consumptive behavior means that students can't distinguish which one is their need and which one is their desire. They buy things that aren't really needed and in fact, many people who are addicted to shopping do so only for pleasure and desire regardless of their own needs, the function of the item, and its value. This behavior will, of course, have a negative impact both in household life and social life. The household budget may be reduced by a significant margin, and can also cause social jealousy among the community. Usually, people who follow a hedonist lifestyle are supported by more than enough income, for example, conglomerates and officials.

The lives of most officials and conglomerates are usually accompanied by luxury and branded goods. Of course, this lifestyle has the possibility of being "inherited" to their children because children usually follow the behavior of the people around them. Apart from financial factors, parenting style can also affect a child's hedonist behavior. Parenting is a complex activity that involves many specific behaviors that both work individually and together to influence children ${ }^{2}$. Parenting also affects the personality of a child. The first interaction of a child is of course with their family. Parents serve as a mirror of their own child's behavior. According to Baumrind, parenting styles are divided into three types, which are, authoritarian parenting, authoritative parenting, and permissive parenting.

These three parenting styles will be discussed further in the next section. Because parenting is as an essential thing in a child's life, it can serve many impacts, both positive and negative, such as hedonism. A good parenting style certainly can have a positive impact on their children, as well as a bad parenting style can have a bad impact on a child. Based on the previous research in 2015, permissive parenting style was the one that causes hedonism (45.8\%), while authoritative parenting led to moderate hedonism (38.0\%), and authoritarian parenting style led to the lowest hedonism lifestyle $(20.1 \%)^{2}$. University students, in this case, are someone who can be considered as a mature and independent person. The way students think is influenced by their parenting style since their childhood. The main reason behind the choosing of this topic is because hedonism may lead to bad lifestyle choices and behaviors. Although there are many other factors that influence the way of thinking and lifestyle of university students, this research will focus on the aspect of parenting style.

\section{Methods}

Based on the collection of the data, this research was observational, based on the data analysis this research was analytic and based on the time this research was cross-sectional. This method was used to know the distribution of parenting style profile in university students of Medicine Program Faculty of Medicine Universitas Airlangga Batch 2015 with the tendency of hedonism. This study was conducted in Universitas Airlangga from 30 September-16 October 2018. The samples used were all 200 students of Medicine Program Faculty of Medicine Universitas Airlangga Batch 2015. Sampling technique used was the total sampling method that fit inclusion and exclusion criteria.

Criteria of inclusion in this research were the agreement of the subjects to participate, subjects are aged 17-23 years old, and are students of Medicine Program Faculty of Medicine Universitas Airlangga Batch 2015. The exclusion criteria in this research was the subject's refusal to participate in this research. This research obtained data from parenting style questionnaire and tendency of hedonism questionnaire. Parenting style questionnaire is from Restu Nurfadhillah research in 2014 called Pengaruh Parenting Style dan Tipe Kepribadian Big Five terhadap Kecenderungan Adiksi Internet that based on Baumrind three factors theory $(1973)$ that has been validated ${ }^{3}$.This questionnaire used the Likert scale and contained 29 statements that can be grouped as 9 statements for authoritarian parenting style, 10 statements for authoritative parenting style, and 10 statements for permissive parenting style.

The parenting style of the students can be determined by comparing the total score of each parenting style group, and the group that got the biggest score determines the student's parenting style. The tendency of hedonism questionnaire was from Agnes Lestari research in 2013 called Pengaruh Gaya Hidup Hedonis terhadap Perilaku Pembelian Impulsif pada Mahasiswa Jurusan PPB 2013 FIP UNY that has been validated ${ }^{4}$. This questionnaire used the Likert scale that contained 32 statements that can be grouped as favorable and unfavorable. There are 19 statements for the favorable group, and 13 statements for the unfavorable group. The category from this questionnaire was divided into three categories which are low, intermediate, and high. The student's category of hedonist tendency can be determined by looking at the total score of the questionnaire and comparing it to the interval. The intervals for each category are: low 32-63; intermediate 64-95; high 96-128. 
The data was presented by a distribution table and analyzed with the k-sample independent non-parametric comparative analytic test. Because the distribution of the data was not normal, so the Chi-Square can't be used, this research used Kruskal-Wallis test using the SPSS 17.0.

The subjects in this research were university students of Medicine Program Faculty of Medicine Universitas Airlangga Batch 2015 that actively participated in lecture, the subject $s$ that meet inclusion and exclusion criteria are 193 students in total. One of the characteristics that can differ the subjects is sex. There are 74 males (38.34\%), and 119 females $(61.66 \%)$ in all respondents.

\begin{tabular}{lcc} 
Results & \multicolumn{2}{c}{ Table 1. Distribution of Sex } \\
\hline Sex & $\Sigma$ & Percentage \\
\hline Male & 74 & $38.34 \%$ \\
Female & 119 & $61.66 \%$ \\
\hline Total & 193 & $100.00 \%$ \\
\hline
\end{tabular}

Table 2. Distribution of Place of Stay

\begin{tabular}{lcl}
\hline Place of Stay & $\Sigma$ & Percentage \\
\hline Boarding House & 88 & $45.60 \%$ \\
Home with & 93 & $48.20 \%$ \\
parents & & \\
Etc & 12 & $6.20 \%$ \\
\hline Total & 193 & $100.0 \%$ \\
\hline
\end{tabular}

Table 3. Distribution of Parenting Style

\begin{tabular}{ccc}
\hline Parenting Style & $\Sigma$ & Percentage \\
\hline Authoritarian & 16 & $8.30 \%$ \\
Authoritative & 169 & $87.56 \%$ \\
Permissive & 8 & $4.14 \%$ \\
\hline Total & 193 & $100.00 \%$ \\
\hline
\end{tabular}

Table 4. Distribution of Tendency of Hedonism

Tendency of $\quad \Sigma \quad$ Percentage

Hedonism

\begin{tabular}{ccc}
\hline Low & 45 & $23.32 \%$ \\
Intermediate & 146 & $75.64 \%$ \\
High & 2 & $1.04 \%$ \\
\hline Total & 193 & $100.00 \%$
\end{tabular}

Other characteristics that can differ the subject are their residences. There are 88 subjects that live in a boarding house $(45.60 \%), 93$ subjects stay with their parents $(48.20 \%)$, and 12 subjects in other places $(6.20 \%)$.

There are 16 subjects raised with an authoritarian parenting style $(8.30 \%), 169$ subjects raised with an authoritative parenting style $(87.56 \%)$, and 8 subjects raised with a permissive parenting style (4.14\%).

There are 45 subjects in the category of low hedonist tendency $(23.32 \%), 146$ subjects in the intermediate tendency of hedonism group ( $75.64 \%)$, and 2 subjects inthe high tendency of hedonism group (1.04\%).
In students with a low tendency of hedonism, there are 2 students raised by authoritarian parenting style (1.04\%), 42 students raised by authoritative parenting style $(21.76 \%)$, and 1 student raised by permissive parenting style $(0.52 \%)$. In students with an intermediate tendency of hedonism lifestyle, there are 12 students raised by authoritarian parenting style $(6.22 \%), 127$ students raised by authoritative parenting style $(65.80 \%)$, and 7 students raised by permissive parenting style (3.62\%). And the last one, in students with high tendency of hedonist lifestyle, is 2 students that had been raised by an authoritarian parenting style (1.04\%).

Research analysis used is to test the research hypothesis about any significant difference between the variables, this research used a Kruskal-Wallis comparative test with SPSS 17.0 for Windows. The reason why KruskalWallis comparative analysis is used because it is an alternative substitute if the Chi-Square's expected value in the cell of the table is less than 5 . The value that this test got is $p=0.123$ with $\alpha=0.05$. Value $p>\alpha$ means that there are no significant differences in the variable. The $p$-value in this research means that there is no significant difference in the variable proportion of Parenting Style in Tendency of Hedonism Lifestyle in university students of Medicine Program Faculty Of Medicine Universitas Airlangga Batch 2015.

\section{Discussion \\ Distribution of Sex}

There were 6 students who did not fill out the questionnaire given by the researcher and also 1 student whose questionnaire was declared invalid. There are some students who were not willing to fill out the questionnaire because there are too many questionnaire items according to some of these students. Besides that, it might be because some of these students did not want to know their parenting style and the tendency of hedonism lifestyle. Then there was 1 student whose questionnaire is invalid because the subject fills all the items questionnaire with the same choice,the "Agree" choice, so the results of that questionnaire was invalidated. The distribution of students in this study was presented in Table 1 which consisted of 74 men (38.34\%) and 119 women (61.66\%).

\section{Distribution of Place of Stay}

In the research conducted on the students of the Faculty of Psychology, Universitas Islam Negeri Sultan Sarif Kasim Riau, $50.55 \%$ of students lived in boarding houses and $49.45 \%$ of students lived at home ${ }^{5}$. According to research in Universitas Syiah Kuala students that graded hedonic consumption based on sex and faculty variables, there were $55.6 \%$ of female students living in boarding houses, $39.4 \%$ of female students who lived with parents, and other categories $5 \%$. Then there were $45.6 \%$ of male students living in boarding houses, $39.4 \%$ of male students living with parents, and $15 \%$ in other categories ${ }^{6}$. 


\begin{tabular}{ccccc}
\hline Parenting Style & Authoritarian & Authoritative & Permissive & Total of Hedonism \\
\hline Low & & & & \\
\hline $\begin{array}{c}\text { Intermediate } \\
\text { High }\end{array}$ & $2(1.04 \%)$ & $42(21.76 \%)$ & $1(0.52 \%)$ & $45(23.32 \%)$ \\
$12(6.22 \%)$ & $127(65.80 \%)$ & $7(3.62 \%)$ & $146(75.64 \%)$ \\
\hline $\begin{array}{c}\text { Total of Parenting } \\
\text { Style }\end{array}$ & $2(1.04 \%)$ & $0(0 \%)$ & $0(0 \%)$ & $\mathbf{1 0 4 \% )}$ \\
\hline
\end{tabular}

Table 5. Parenting Style in Tendency of Hedonism

This research (48.20\% living with parents) and the previous research $(50.55 \%$ of students live in boarding houses), shows that the distribution of student residences in previous studies is different from this research because the population, sample, and place of research are different.

\section{Distribution of Parenting Style}

One thing that gave a very big influence on adolescent growth and development is parenting style. Ideally, adolescent growth would be optimal if it's accompanied by the guidance of the family. This guidance from the family needed to be warm and harmonious so that all of the child's needs, both psychological and physical, can be fulfilled which will, in turn, encourage them to become a virtuous person ${ }^{7}$. In the study on the students of the Faculty of Economics, Universitas Negeri Yogyakarta, the data was almost the same with this research with the most common parenting style in students are authoritative parenting style that makes it $61 \%$ of the total, in the second position there was authoritarian parenting with $27 \%$, and the least common parenting style in students are permissive parenting style with percentage of $12 \% 8$.

In addition, the authoritative parenting style in this research is higher than the research conducted in UIN Syarif Hidayatullah students in Jakarta with the highest parenting style percentage is permissive parenting style with a percentage of $35.0 \%$, followed by authoritarian parenting $34.0 \%$ and finally authoritative parenting style with a percentage of $31.0 \%^{3}$. Between this research and the research of UIN Syarif Hidayatullah Jakarta students, it's found that the result is different due to the different population, sample, and place of research used.

\section{Distribution of Tendency of Hedonism}

In the research on students of PPB major of FIP UNY 2013, the most common category of hedonist lifestyle tendency in students was the moderate category with a percentage of $76 \%$, then ranked second is the low category with a percentage of $19 \%$, and high with $5 \%$ of the population ${ }^{4}$. In other studies on hedonism, there was the same ranking category, with the most results in the moderate category with a percentage of $68.4 \%$, and the low category with a percentage of $15.8 \%$, and the high category with $15.8 \%$ in the last place ${ }^{9}$. It was the same results with this research data with the most types of hedonism in students were moderate in form of hanging out with friends and buying snacks and foods.

\section{Parenting Style in Tendency of Hedonism}

In Table 5 it can be seen that 16 students $(8.30 \%)$ were raised by authoritarian parenting style, 169 students were raised by authoritative parenting style $(87.56 \%)$, and 8 students were raised by permissive parenting style $(4.14 \%)$. Next is the tendency of hedonist lifestyle in students, 45 students included in the category have a low tendency of hedonism (23.32\%), then 146 students belonged to the moderate tendency of hedonism category (75.64\%), and 2 people belonged to the category of low hedonist tendencies (1.04\%). In students with a tendency of hedonist lifestyles in the low category there were 2 people who were raised with authoritarian parenting $(1.04 \%), 42$ people raised by authoritative parenting $(21.76 \%)$, and there was 1 student raised by permissive parenting $(0.52 \%)$.

In students with the moderate category of hedonist lifestyle tendencies, there were 12 students raised by an authoritarian parenting style $(6.22 \%), 127$ students raised by an authoritative parenting style $(65.80 \%)$, and 7 studentsraised by a permissive parenting style (3.62\%). And finally, for students with a high tendency of hedonist lifestyle, there were two people raised by authoritarian parenting $(1.04 \%)$. The 2 people with authoritarian parenting style which fell to the high hedonist tendencies category may be feeling stressed at home and as a result, vented their frustrations through a hedonist lifestyle, which was done by having fun with friends or buying various items that weren't really needed.

The variable in this study was the Tendency of Hedonist Lifestyle. To test for the presence or absence of the significant differences, a Kruskal-Wallis statistical comparison test was used with the help of SPSS Statistics 17 for Windows software. The calculation results obtained is $p=0.123$ with a value of $\alpha=0.05$. The value of $p>a$ means that there was no significant difference so that parenting does not affect the tendency of the hedonist lifestyle. So from that, it could be concluded that from the comparative study that has been done there was no difference in significant proportions of parenting criteria on 
the tendency of hedonist student lifestyle which means this is contrary to the hypothesis.

Limitations from this research were that this research only examines one of the factors that can influence the tendency of hedonism lifestyles, in this research the researchers have to wait for the questionnaire to fill in for a long time because the questionnaire was done online, in addition the number of items in the questionnaire was quite numerous which may have made some respondents unwilling to be the subject, furthermore this research used Google Docs for data collection so that there was a possibility that those who filled in the questionnaire were not the actual respondents, and the researchers could not see the condition of the respondents while filling out the questionnaire so that the researcher could not see if the subjects were distracted or not.

\section{Conclusion}

The most common type of parenting styles of students of the Medicine Program, Faculty of Medicine, Airlangga University, 2015 was the authoritative parenting style. The most common category of hedonist tendency lifestyle in students of the Medical Education Department of the Faculty of Medicine, Universitas Airlangga 2015 was the intermediate category. The type of parenting style that had the lowest tendency of hedonist lifestyle in the students of the Medical Education Department of the Faculty of Medicine, Universitas Airlangga 2015 was an authoritative parenting style. The type of parenting style that had the moderate tendency of hedonist lifestyle in students of the Medical Education Department of the Faculty of Medicine, Universitas Airlangga 2015 was the authoritative parenting style.The type of parenting style that had the highest tendency of hedonist lifestyle in the students of the Department of Medical Education, Faculty of Medicine, Universitas Airlangga 2015 is an authoritarian parenting style. And lastly, in the comparative study that had been done, there was no significant difference in the proportion of the type of parenting style with the category tendency of hedonism lifestyle in the students of Medical Education Department of the Faculty of Medicine, Universitas Airlangga 2015 ( $p$-value $=0.123)$.

\section{CONFLICT OF INTEREST}

The author stated there is no conflict of interest

\section{REFERENCES}

1.Pontania A. Hubungan Antara Konsep Diri dengan Gaya Hidup Hedonis pada Siswa SMA Negeri 4 Surakarta. Universitas Muhammadiyah Surakarta, 2016.

2. Budiarsih K. Hubungan Antara Jenis Pola Asuh dengan Gaya Hidup Hedonismepada Remaja SMK NEGERI 7 Tangerang. 2015.

3. Nurfadhilah R. Pengaruh Parenting Style dan Tipe Kepribadian Big Five terhadap Kecenderungan Adiksi Internet. 2014.
4. Nurvitria AL. Pengaruh Gaya Hidup Hedonis terhadap Perilaku Pembelian Impulsif pada Mahasiswa Jurusan Ppb 2013 Fip Uny. Jurnal Riset Mahasiswa Bimbingan dan Konseling. 2015.

5. Nisak K. Perbedaan Gaya Hidup Hedonis Mahasiswa Psikologiyang Tinggal di Kos dan Tinggal di Rumah Orang tua. Universitas Islam Negeri Sultan Sarif Kasim Riau, 2014.

6. Riadhah CA and Rachmatan R. Perbedaan Konsumsi Hedonispada Mahasiswa Universitas Syiah KualaDitinjaudari Jenis Kelamindan Asal Fakultas. Psympathic: Jurnal IImiah Psikologi. 2016; 3: 179-90.

7. Aini LN. Hubungan Pola Asuh Orang Tua dengan Kenakalan Remaja di RW V Kelurahan Sidokare Kecamatan Sidoarjo. Jurnal Keperawatan dan Kebidanan. 2017; 6.

8. Setyanto GG. Pengaruh Self-Regulated Learning dan Pola Asuh Orang Tua terhadap Prokrastinasi Akademik Mahasiswa Fakultas Ekonomi Universitas Negeri Yogyakarta. Yogyakarta: UNY. 2014.

9. Kresdianto D. Hubungan Gaya Hidup Hedonis dengan Perilaku Konsumtif Fashion Pakaian pada Mahasiswi di Fakultas Psikologi UIN Maliki Malang. Universitas Islam Negeri Maulana Malik Ibrahim, 2014. 